\title{
RAPID AND SENSITIVE DETECTION OF LAWSONIA INTRACELLULARIS IN PIGS BY REAL-TIME LOOP-MEDIATED ISOTHERMAL AMPLIFICATION
}

\author{
PARK Byung-Yong ${ }^{1}$, SHIM Kwan-Seob ${ }^{2}$, KIM Won-Il ${ }^{1}$, HOSSAIN Md Mukter ${ }^{1}$, \\ KIM Bumseok ${ }^{1}$, KWON Jungkee ${ }^{1}$, PARK Choi-Kyu ${ }^{3}$, CHO Sung-Jin ${ }^{4}$, JO Inho ${ }^{5}$, \\ $\mathrm{CHO}$ Ho-Seong, ${ }^{1 *}$
}

\begin{abstract}
${ }^{1}$ College of Veterinary Medicine and Bio-Safety Research Institute, Chonbuk National University, Jeonju 561-756, Republic of Korea; ${ }^{2}$ Department of Animal Biotechnology, Chonbuk National University, Jeonju 561-756, Republic of Korea; ${ }^{3}$ College of Veterinary Medicine, Kyungpook National University, Daegu 702-701, Republic of Korea; ${ }^{4}$ Department of Biology, College of Natural Sciences, Chungbuk National University, Cheongju, Chungbuk 361-763, Republic of Korea; ${ }^{5}$ Department of Molecular Medicine and Ewha Medical Research Institute, Ewha Womans University Medical School, Seoul 158710, Republic of Korea
\end{abstract}

(Received 2nd August; Accepted 22 $2^{\text {nd }}$ December 2014)

A simple and rapid real-time loop-mediated isothermal amplification (LAMP) assay designed to detect Lawsonia (L.) intracellularis, an important bacteria causing proliferative enteropathy in pigs. A set of four primers targeting the ubiquinone/menaquinone biosynthesis methylase ( $u b i \mathrm{E})$ gene was designed for the LAMP reaction. Additionally, serial 10-fold dilutions of cultured $L$. intracellularis and spiked feces were also used for the optimization of real-time LAMP. The lower limit of the linear range of the assay in L. intracellularis was $1.0 \times 10^{\circ} \mathrm{L}$. intracellularis. Real-time LAMP was 10 and 100 times more sensitive than real-time PCR and conventional PCR detection methods, respectively. Based on testing of 213 porcine fecal samples using real-time LAMP, realtime PCR and PCR, the agreement quotients of real-time LAMP with conventional PCR and with real-time PCR were 0.77 and 0.95 , respectively. This study demonstrated that real-time LAMP was a powerful tool for the rapid and sensitive detection of $L$. intracellularis in porcine fecal samples.

Key words: Lawsonia intracellularis, pig, porcine proliferative enteropathy, real-time loopmediated isothermal amplification.

\section{INTRODUCTION}

Each year, porcine proliferative enteropathy (PPE) caused by Lawsonia (L.) intracellularis causes enormous economic losses in intensive pig production systems all over the world $[1,2]$. The animals affected are usually growing and mature pigs with nonspecific diarrhea, retarded growth rate and weight loss. A rapid and accurate method for the

Corresponding author: e-mail: hscho@jbnu.ac.kr 
diagnosis of the disease is the first and foremost target to provide efficient treatment procedures, as well as supporting prevention measures thereby minimizing losses.

L. intracellularis is the causative agent of PPE, a fastidious and obligate intracellular bacteria that can be cultivated and maintained only in cell cultures [3]. Thus, isolation is not routinely used to detect $L$. intracellularis for diagnostic purposes in clinical conditions [4]. Therefore, a diagnostic approach to identify the specific DNA from tissue samples by PCR and immunohistochemistry has been suggested as the "gold standard" [4]. In addition, more reliable and sensitive methods of diagnosis, namely several PCR-based assays including PCR and real-time PCR have been established in the recent years to detect $L$. intracellularis [4-6]. Between these methods, real-time PCR provides the best sensitivity and specificity with a detection limit of three cells per reaction [5]. Although the performance of real-time PCR assay was more sensitive for the detection of L. intracellularis, but required expensive fluorescence detector-based thermocyclers.

A new technology alternative to real time PCR-based detection methods named realtime loop-mediated isothermal amplification (LAMP) has been established. This technique involves auto-cycling strand-displacement DNA synthesis performed by Bst DNA polymerase, which has a high strand displacement activity based on a set of specific primers that recognize a total of six distinct sequences on the target DNA. Importantly, because the LAMP assay synthesizes a large amount of DNA, the byproduct of which is an insoluble white precipitate of magnesium pyrophosphate, the amplified target DNA can be assessed using simple turbidity analysis [7,8]. Recently, real-time loop-mediated isothermal amplification (real-time LAMP) was developed to amplify nucleic acids with high specificity and sensitivity, allowing quantitative analysis of nucleic acid templates [9]. During the LAMP reaction, an insoluble byproduct, magnesium pyrophosphate, is produced in proportion to the amounts of the target DNA to be amplified. Therefore, real-time quantification can be achieved by measuring the turbidity caused by magnesium pyrophosphate using an inexpensive photometer [10].

The purpose of this study was to develop and validate the LAMP assay for the rapid and accurate detection of $L$. intracellularis in porcine fecal samples. For a sensitive detection of $L$. intracellularis from fecal samples by LAMP reaction, a set of highly specific primers were designed. The results obtained from this assay were compared with the results of PCR and real-time PCR assays that are used nowadays to detect $L$. intracellularis DNA in fecal samples of clinically ill pigs.

\section{MATERIALS AND METHODS}

\section{Bacterial strains and DNA isolation}

For the sensitivity and specificity of the selected primers, real-time LAMP assay was conducted with L. intracellularis B3903 (Boehringer Ingelheim Vetmedica, Inc., 
St. Joseph, MO, USA) and 11 non-L. intracellularis bacteria (Brachyspira byodysenteriae American Type Culture Collection [ATCC] 35218, Brachyspira pilosicoli [ATCC 51139], Campylobacter coli [field isolate], Campylobacter jejuni [field isolate], Clostridium perfringens [field isolate], Escherichia coli [ATCC 25922], hemolytic Escherichia coli [ATCC 35218], Salmonella typhimurium [ATCC 14028], S. cholerasuis [field isolate], Shigella flexneri [ATCC 12022], and Yersinia enterocolitica [ATCC 9610]).

A silica-membrane-based spin kit $\left(\mathrm{DNeasy}^{\circledR}\right.$ Tissue kit; Qiagen GmbH, Hilden, Germany) was used for the extraction and purification of Chromosomal DNA from these adjusted bacterial suspensions according to the manufacturer's instructions. Extracted DNA samples were then stored at $-20^{\circ} \mathrm{C}$ until further use.

\section{Spiking of fecal samples and DNA isolation}

One hundred microliters of a sterile saline suspension with a known concentration of $L$. intracellularis in the range of $10^{\circ}$ to $10^{3} \mathrm{TCID}_{50}$ was added to fresh fecal samples. Bacterial DNA from the spiked fecal samples were extracted from the centrifuged pellet samples using the AccuPrep ${ }^{\circledR}$ Stool DNA extraction kit (Bioneer Co., Daejeon, Korea) according to the instructions by the manufacturer. Briefly, the fecal samples (200 mg) were suspended in stool lysis buffer (Bioneer Co., Daejeon, Korea), which is designed to remove inhibitory substances from stool samples. Following proteinase $\mathrm{K}(20 \mu \mathrm{l})$ treatment the samples were bound to a silica-gel based capture membrane, washed and then eluted in a low-salt buffer. The eluted DNA was used as the template for the amplification of real-time LAMP, real-time PCR and PCR.

\section{Real-time LAMP assay}

The real-time LAMP assay was performed as described previously [11]. Briefly, realtime LAMP requires a set of four primers (B3, F3, BIP, and FIP) within the target DNA. Primers of real-time LAMP reactions for $L$. intracellularis were designed against the ubiquinone/menaquinone biosynthesis methylase ( $u b i \mathrm{E}$ ) gene using Primer Explorer V4 Software (FUJITSU, Tokyo, Japan). Primers designed for real-time LAMP along with the primers used for PCR and real-time PCR are described in Table 1. The realtime LAMP reaction was performed using a Loopamp DNA amplification kit (Eiken Chemical Co. Ltd., Tokyo, Japan) with a $24-\mu l$ reaction mixture containing $1 \mu \mathrm{l}(40 \mathrm{pM})$ each of primers LI-BIP and LI-FIP, $1 \mu \mathrm{l}(5 \mathrm{pM})$ of primers LI-F3 and LI-B3, $12.5 \mu \mathrm{l}$ of a $2 \mathrm{x}$ reaction mixture, and $5 \mu \mathrm{l}$ of target DNA. Reactions were incubated at $96^{\circ} \mathrm{C}$ for $5 \mathrm{~min}$ for heat denaturation, followed by addition of $1 \mu \mathrm{l}$ Bst DNA polymerase to bring the volume of the final reaction mixture to $25 \mu \mathrm{l}$, after which the mixture was incubated at $65^{\circ} \mathrm{C}$ for 60 min using an LA-500 turbidimeter (Teramecs Co., Ltd., Kyoto, Japan). The cutoff turbidity value for discriminating between positive and negative samples was 0.1 , which is two times more than the average turbidity value of negative controls of several replicates [12]. 


\section{Sensitivity and specificity test}

The suitability of the assay for detection of L. intracellularis was evaluated by comparing the detection results of the real-time LAMP assay using 213 fecal samples obtained from each of 213 pigs, from ten pig farms, that had been diagnosed clinically with $L$. intracellularis infection. A sterile swab was used for the collection of fecal samples, after collection. The swabs were immediately immersed in a $1.5 \mathrm{ml}$ tube containing $400 \mu \mathrm{l}$ Tris-EDTA buffer $(10 \mathrm{mM}$ Tris-HCl, $1 \mathrm{mM}$ EDTA, $\mathrm{pH} 7.4$ ) and stored at $-20^{\circ} \mathrm{C}$ until used. L. intracellularis B3903 was used as the positive control. DNA was extracted from the collected feces and from L. intracellularis-infected (positive control) and non-infected (negative control) fecal samples using the AccuPrep ${ }^{\circledR}$ Genomic DNA extraction kit (Bioneer, Co., Deojeon, Korea) according to the manufacturer's instructions. The isolated DNA was used as the template for real-time LAMP, real-time PCR and PCR.

\section{Real-time PCR and PCR assay}

Real-time PCR and PCR assay were conducted as described previously [6,13]. Primers used in this study are listed in Table 1.

Table 1. Primer sequences of real-time loop-mediated isothermal amplification (LAMP), real-time PCR and PCR used in this study

\begin{tabular}{lllll}
\hline Method & Primer & Position $^{*}$ & Sequence ( 5'-3') & References \\
\hline & LI-F3 & $18627-18647$ & ATCCAAATACGTTGTTTTCCT & \\
& LI-B3 & $18796-18813$ & GGCCAATAACAGCAGACG & \\
$\begin{array}{l}\text { Real-time } \\
\text { LAMP }\end{array}$ & LI-FIP(F1c+F2) & $18688-18709$ & TTCTCTGAAATTGCGAGAGTCC + & This study \\
& LI-BIP(B1c+B2) & $18716-18738$ & TGTACGAGGGACAATATTACGGA + & \\
& & $18768-18788$ & TTTACCGTTTCCTGATTCTTG & \\
Real-time & Li-F & $1142217-1142198$ & GCTGTGGATTGGGAGAAATC & \\
PCR & Li-R & $1142056-1142074$ & CAAGTTGACCAGCCTCTGC & \\
PCR & LIF & $1142959-1142937$ & GCAGCACTTGCAAACAATAAACT & \\
\hline
\end{tabular}

* Genome position according to Genbank Accession number AM180252.

\section{Data analysis}

The sensitivity and specificity among these three assays were compared and the agreement among the assays was examined using kappa statistics [7]. The linear regression model was performed between a plot of the amplification time required to exceed the turbidity level of 0.1 (Tt) versus the log of the initial template DNA [12]. 


\section{RESULTS}

The success of real-time LAMP assay depends on the specificity of a set of primers designed. To determine the specificity of the primers used in the L. intracellularis realtime LAMP assay, L. intracellularis bacterial DNA, along with other non- $L$. intracellularis DNA was demonstrated that those primers specifically bind to target DNA of $L$. intracellularis but not to the DNA from others not L. intracellularis (Table 2). The results confirmed that these primer sequences are specific for L. intracellularis. The measurement of real-time turbidity in the real-time LAMP assay containing from $1 \times$ $10^{0}$ to $1 \times 10^{3} \mathrm{~L}$. intracellularis of template DNA are shown in Table 3. Using 10-fold serial dilutions of spiked fecal samples, we determined that the detection limit of real-time LAMP was $10^{\circ} \mathrm{L}$. intracellularis bacteria, compared to $10^{1} \mathrm{~L}$. intracellularis for real-time PCR and $10^{2} \mathrm{~L}$. intracellularis for PCR (Figure 1).

Table 2. Specificity of real-time loop-mediated isothermal amplification assay

\begin{tabular}{lc}
\hline Species & No. of positive strains/total $^{\mathbf{a}}$ \\
\hline Brachyspira spp. & $0 / 2$ \\
B. hyodysenteriae & $0 / 1$ \\
B. pilosicoli & $0 / 1$ \\
Campylobacter spp. & $0 / 2$ \\
Campylobacter coli & $0 / 1$ \\
Campylobacter jejuni & $0 / 1$ \\
Clostridiumperfringens & $0 / 1$ \\
Eschericbia coli & $0 / 2$ \\
Salmonella spp. & $0 / 2$ \\
S. typhimurium & $0 / 1$ \\
S. cholerasuis & $0 / 1$ \\
Shigella flexneri & $0 / 1$ \\
Yersinia enterocolitica & $0 / 1$ \\
\hline
\end{tabular}

${ }^{a}$ Number of strains giving positive results in the real-time LAMP assay per total number tested

Table 3. Results of $T_{t}$ values obtained from the real-time turbidimeter

\begin{tabular}{ccccc}
\hline \multirow{2}{*}{ Bacterial DNA } & \multicolumn{4}{c}{$\mathbf{T}_{\mathbf{t}}(\mathbf{m i n})^{\mathbf{a}}$} \\
\cline { 2 - 5 } & Run1 & Run2 & Run3 & Mean \pm S.D. \\
\hline $1 \times 10^{3}$ & 28.01 & 26.60 & 25.10 & $26.57 \pm 1.46$ \\
$1 \times 10^{2}$ & 30.02 & 30.60 & 32.00 & $30.87 \pm 1.02$ \\
$1 \times 10^{1}$ & 38.20 & 36.13 & 39.90 & $38.08 \pm 1.89$ \\
$1 \times 10^{0}$ & 49.50 & 50.52 & 56.01 & $52.01 \pm 3.51$ \\
\hline
\end{tabular}

${ }^{\mathrm{a}} T_{t}$ is defined as the time required for the turbidity of the real-time LAMP reaction to exceed 0.1 . 


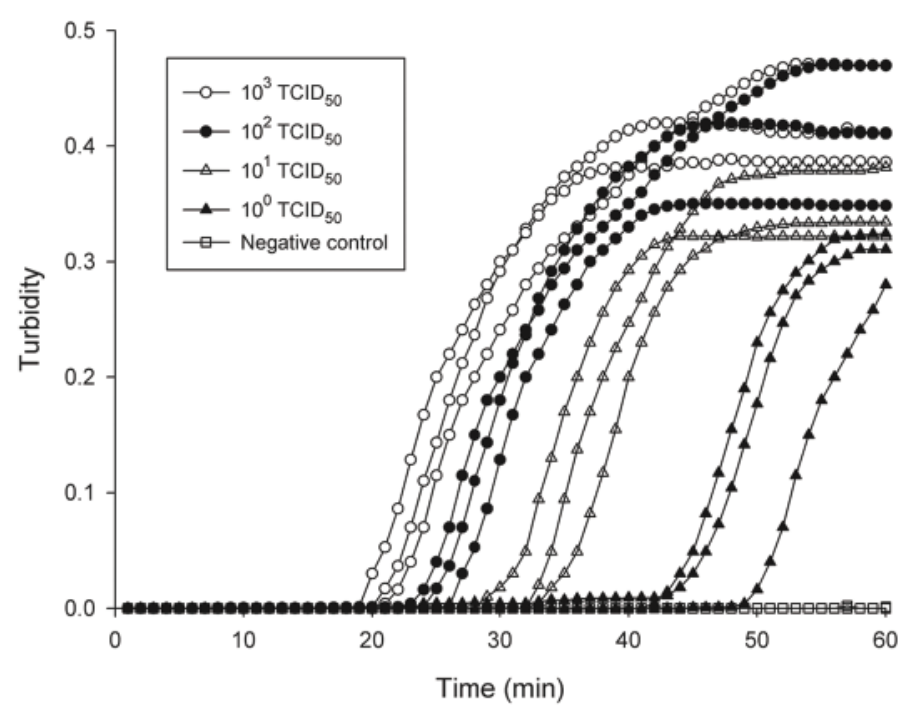

Figure 1. Detection of Lawsonia intracellularis-DNA using the real-time loop-mediated isothermal amplification (LAMP) assay. A turbidity of 0.1 was considered to be positive

\section{DISCUSSION}

Results of the real-time LAMP, real-time PCR and PCR assays of 213 fecal samples from nine pig farms are shown in Table 4. One hundred seventy-one fecal samples $(80.3 \%)$ were positive by both real-time LAMP and real-time PCR; 3 samples $(1.4 \%)$ were also positive by real-time LAMP but negative by real-time PCR; no sample ( $0 \%$ ) was positive by real-time PCR and negative by real-time LAMP; and 39 (18.3\%) were negative by both tests. The agreement quotients (kappa), which measure the levels of agreement beyond that of random chance, were 0.77 and 0.95 , respectively (Table 5). There were three discordant samples that were positive according to real-time LAMP but negative with real-time PCR. Together, these results indicate a very high sensitivity with respect to real-time LAMP assay regarding the detection of L. intracellularis. Based on the higher analytical sensitivity of the real-time LAMP assay, it is likely that 17 discordant samples were positive but with levels below the detection limit of PCR.

In the recent years, real-time LAMP has gained popularity for its usefulness in the detection of several pathogens because of its sensitivity, specificity, and ease of use compared to conventional methods such as PCR and real-time PCR [14]. Further on, PCR requires up to $4 \mathrm{~h}$ for the completion of one reaction, real-time PCR is slower and more costly than real-time LAMP. In this study, the amount of template DNA was assessed in real-time by reading the $\mathrm{OD}_{650}$ every $6 \mathrm{~s}$ in a LoopAmp real-time turbidimeter. The real-time turbidity measurements curve had high linearity (Figure 1) which is the same as in real-time PCR [6]. This finding indicates that the concentration of any template DNA can be determined by comparing the Ttvalue with the Ttvalues 
of template DNA samples of known concentrations. Thus, using a real-time turbidity monitoring system, the concentrations of $L$. intracellularis DNA in clinical samples can be quantified. A novel method utilizing real-time LAMP assays to detect L. intracellularis DNA from pig fecal samples was developed in this study. Real-time LAMP offers several advantages over PCR detecting $L$. intracellularis DNA using feces from pigs. In particular, LAMP assay is a sensitive method and can be amplified 10 copies of each DNA strand in less than $1 \mathrm{~h}$ under isothermal conditions.

Table 4. Comparison of PCR and real-time PCR with results of real-time LAMP for detection of Lawsonia intracellularis in 213 fecal samples obtained from pigs on ten Korean farms

\begin{tabular}{cccccccc}
\hline Farm & $\begin{array}{c}\text { No. of } \\
\text { samples }\end{array}$ & \multicolumn{2}{c}{ Real-time LAMP } & \multicolumn{2}{c}{ Real-time PCR } & \multicolumn{2}{c}{ PCR } \\
\cline { 3 - 8 } & Positive & Negative & Positive & Negative & Positive & Negative \\
\hline 1 & 21 & 15 & 6 & 14 & 7 & 12 & 9 \\
2 & 34 & 32 & 2 & 32 & 2 & 29 & 5 \\
\hline 3 & 17 & 13 & 4 & 13 & 4 & 9 & 8 \\
\hline 4 & 23 & 15 & 8 & 15 & 8 & 13 & 10 \\
\hline 5 & 23 & 21 & 2 & 20 & 3 & 15 & 8 \\
\hline 6 & 26 & 23 & 3 & 23 & 3 & 19 & 7 \\
\hline 7 & 16 & 15 & 1 & 15 & 1 & 14 & 2 \\
8 & 21 & 17 & 4 & 16 & 5 & 16 & 5 \\
\hline 9 & 12 & 7 & 5 & 7 & 5 & 5 & 7 \\
10 & 20 & 16 & 4 & 16 & 4 & 12 & 8 \\
\hline Total & 213 & 174 & 39 & 171 & 42 & 144 & 69 \\
\hline
\end{tabular}

Table 5. Comparison of the sensitivities and specificities of PCR, real-time PCR and real-time LAMP for detection of Lawsonia intracellularis in 213 fecal samples of pigs

\begin{tabular}{lcccc}
\hline & & \multicolumn{2}{c}{ Real-time LAMP } & \multirow{2}{*}{ Kappa index } \\
\cline { 3 - 4 } & & $\mathbf{( + )}$ & $\mathbf{( - )}$ & \\
\hline PCR & $(+)$ & 157 & 0 & 0.77 \\
& $(-)$ & 17 & 39 & \\
Real-time & $(+)$ & 3 & 0 & 0.95 \\
PCR & $(-)$ & & 39 & \\
\hline
\end{tabular}

A previous study [15] found that the detection limit of a real-time LAMP assay for Ehrlichia ruminantium was 10 copies per reaction, which is at least 10 times more sensitive than PCR but slightly less sensitive than real-time PCR. In the current study, real-time LAMP was 10 and 100 times more sensitive than real-time PCR and PCR, respectively. As suggested previously [16], the addition of a heat-denaturation step increased assay sensitivity. Specifically, heat denaturation resulted in the increased 
detection of L. intracellularis DNA in the positive control and a higher detection rate in clinical fecal samples.

In Korea, the reported prevalence of PPE ranges from 44\% to 69\% in individual pigs, as determined by indirect immunofluorescence antibody testing [16]. However, the detection rate of $L$. intracellularis using PCR is 7.9\% (15 of 191 samples) [17]. Although it is somewhat difficult to directly compare the prevalence of PPE as determined by different methods, the prevalence of PPE has decreased due to the use of antibiotics. Indeed, the use of veterinary pharmaceuticals in Korea is typically greater than in most other countries [18]. Specifically, approximately 600 tons of veterinary antimicrobials were used as feed additives in Korea in 2004, which is 20-fold higher than the amount of growth promoters used in the United Kingdom in the same year [19]. The Korea Food and Drug Administration banned the use of all types of antibiotics in feedstuffs for livestock and farm-raised fish in 2012, which increased the prevalence of PPE. Therefore, it is an ideal time to develop a highly sensitive and useful real-time LAMP assay for the detection of $L$. intracellularis.

Besides pigs, there are reports of isolating L. intracellularis from a wide range of animal species including hamsters, horses, guinea pigs, dogs, lambs, calves, ferrets, foxes, deer, rabbits, rats, mice, ratites, wild boars, wolves, giraffes, hedgehogs, and primates [1]. The broad range of multiple host species is questionable to whether natural cross-species transmission might occur. L. intracellularis (order Desulfovibrionalies, family Desulfovibrionaceae), an obligately intracellular bacterium is the etiological agent of proliferative enteropathy. It causes proliferation of the affected enterocytes characterized by crypt hyperplasia of immature cells [20]. Similar lesions have been found in other patients suffering from coeliac diseases. There is a hypotheses that a similar etiological agent is probably responsible for this malady. It was also previously suggested to be a possible agent of human ulcerative colitis. However, the etiological role of the bacterium was not established and has never been reported in humans [21]. Cross-species transmission among pigs, horses, hamsters and mice has been demonstrated experimentally. Therefore, it is very difficult to conclude regarding the risk of human infections, but recent reports of the disease in non-human primates suggest that, as diagnostic methods improve, the disease may be detected in humans.

In conclusion, Real-time LAMP assay developed in this study was shown to be an accurate diagnostic method for the rapid detection of $L$. intracellularis in porcine clinical samples. To the best of our knowledge, it is the first report to document the detection of $L$. intracellularis by real-time LAMP assay in pig fecal samples.

\section{Acknowledgement}

This work was carried out with the support of "Cooperative Research Program for Agriculture Science \& Technology Development (Risk assessment research on exposure of biological, chemical and environmental agents in livestock, PJ01052303)" Rural Development Administration, Republic of Korea. 


\section{REFERENCES}

1. Lawson GHK, Gebhart CJ: Proliferative Enteropathy. J Comp Pathol 2000, 122:77-100.

2. Kovačocyová K, Reichel P, Seidel H, Brenesselová M, Kósa B. Influence of beta-glucan and vaccination against Lawsonia intracellularis on selected immune indices in weaned piglets. Acta Vet-Beograd 2014, 64(1):105-114.

3. McOrist S, Lawson GH: Porcine proliferative enteropathy. Vet Rec 1993, 132:368-368.

4. Jordan DM, Knittel JP, Roof MB, Schwartz K, Larson D, Hoffman LJ. Detection of Lawsonia intracellularis in swine using polymerase chain reaction methodology. J Vet Diagn Invest 1999, 11(1):45-49.

5. Drozd M, Kassem II, Gebreyes W, Rajashekara G. A quantitative polymerase chain reaction assay for detection and quantification of Lawsonia intracellularis. J Vet Diagn Invest 2010, 22(2):265-269.

6. Wattanaphansak S, Gebhart CJ, Anderson JM, Singer RS. Development of a polymerase chain reaction assay for quantification of Lawsonia intracellularis. J Vet Diagn Invest 2010, 22(4):598-602.

7. Cho HS, Kang JI, Park NY. Detection of canine parvovirus in fecal samples using loopmediated isothermal amplification. J Vet Diagn Invest 2006, 18(1):81-84.

8. Hwang ES, Lee TU, Jung DY, Cho HS. Development of loop-mediated isothermal amplification method for the rapid and sensitive detection of bovine tuberculosis in Korea native cattle. Korean J Vet Serv 2011, 34(4):333-339.

9. Notomi T, Okayama H, Masubuchi H, Yonekawa T, Watanabe K, Amino N, Hase T. Loopmediated isothermal amplification of DNA. Nucleic Acids Res 2000, 28:e63.

10. Mori Y, Nagamine K, Tomita N, Notomi T. Detection of loop-mediated isothermal amplification reaction by turbidity derived from magnesium pyrophosphate formation. Biochem Biophys Res Commun 2001, 289(1):150-154.

11. Suzuki R, Ihira M, Enomoto Y, Yano H, Maruyama F, Emi N, Asano Y, Yoshikawa T. Heat denaturation increases the sensitivity of the cytomegalovirus loop-mediated isothermal amplification method. Microbiol Immunol 2010, 54(8):466-470.

12. Saleh M, Soliman H, El-Matbouli M. Loop-mediated isothermal amplification as an emerging technology for detection of Yersinia ruckeri the causative agent of enteric red mouth disease in fish. BMC Vet Res 2008, 4:31.

13. Suh DK, Song JC. Simultaneous detection of Lawsonia intracellularis, Brachyspira byodysenteriae and Salmonella spp. In swine intestinal specimens by multiplex polymerase chain reaction. J Vet Sci 2005, 6(3):231-237.

14. Guedes RM, Gebhart CJ, Winkelman NL, Mackie-Nuss RA, Marsteller TA, Deen J. Comparison of different methods for diagnosis of porcine proliferative enteropathy. Can J Vet Res 2002, 66(2):99-107.

15. Nakao R, Stromdahl EY, Magona JW, Faburay B, Namangala B, Malele I, Inoue N, Geysen D, Kajino K, Jongejan F, Sugimoto C. Development of loop-mediated isothermal amplification (LAMP) assays for rapid detection of Ehrlichia ruminantium. BMC Microbiology 2010, 10:296.

16. Lee SW, Kim TJ, Park SY, Song CS, Chang HK, Yeh JK, Park HI, Lee JB. 2001. Prevalence of porcine proliferative enteropathy its control with tylosin in Korea. J Vet Sci 2001, 2:209212. 
17. Chu JQ, Hu XM, Kim MC, Park CS, Jun MH. 2010. Detection and genetic characterization of Lawsonia intracellularis from swine in Korea. Korean J Vet Serv 2010, 33(3):223-231.

18. Han F, Ge B. Quantitative detection of Vibrio vulnificus in raw oysters by real-time loopmediated isothermal amplification. Int J Food Microbiol 2010, 142(1-2):60-66.

19. Kim Y, Jung J, Kim M, Park J, Boxall AB, Choi K. Prioritizing veterinary pharmaceuticals for aquatic environment in Korea. Environ Toxicol Pharmacol 2008, 26(2):167-176.

20. Gonkowski S, Burlinski P, Calka J: Proliferative entreropathy (PE) - induced changes in galanin - like immunoreactivity in the enteric nervous system of the porcine distal colon. Acta Vet-Beograd 2009, 59(4):321-330.

21. Jacobson M, Råsbäck T, Flöistrup H, Benz M, Braun-Fahrländer C, Riedler J, SchramBijkerk D, Fellström C. Survey on the occurrence of Brachyspira species and Lawsonia intracellularis in children living on pig farms. Epidemiol Infect 2007, 135(6):1043-1045.

\section{REAL TIME LOOP-MEDIATED IZOTERMALNA AMPLIFIKACIJA - OSETLJIVA I BRZA METODA ZA DETEKCIJU LAWSONIA INTRACELLULARIS KOD SVINJA}

PARK Byung-Yong, SHIM Kwan-Seob, KIM Won-Il, HOSSAIN Md Mukter, KIM Bumseok, KWON Jungkee, PARK Choi-Kyu, CHO Sung-Jin, JO Inho, CHO HoSeong

Razvijena je jednostavna i brza metoda - Real time loop-mediated izotermalna amplifikacija (LAMP), namenjena za dokazivanje Lawsonia (L.) intracelullaris, značajne bakterije koja kod svinja izaziva proliferativnu enteropatiju. Za izvođenje metode, dizajniran je set od četiri prajmera koji su specifični za biosintezu ubiquinon/menaquinon metilaze (ubiE) gen. Pored toga, za optimizaciju real-time LAMP metode, upotrebljene su i desetorostruka serijska razređenja čiste kulture L. intracellularis, kao i brisevi fecesa. Donja granica linearnog niza rezultata za L. intracellularis bila je 1,0 x 100 . Real-time LAMP metoda je bila 10 puta osetljivija u poređenju sa real-time PCR i 100 puta osetljivija u odnosu na konvencionalnu PCR metodu. $\mathrm{Na}$ osnovu rezultata ispitivanja 213 uzoraka fecesa svinja, koristeći real-time LAMP metodu, real-time PCR i PCR, stepen podudarnosti real-time LAMP sa konvencionalnim real-time PCR testom bio je 0,77, a sa PCR testom 0.95. Rezultati studije pokazuju da je real-time LAMP pouzdan metod za brzu i osetljivu detekciju L. intracellularis u uzorcima fecesa svnja. 